\title{
NA CONFLUÊNCIA DA PROSA E DA POESIA: NIKETCHE, UM ROMANCE LÍRICO
}

James Rios de Oliveira Santos* Luzia Aparecida Berloffa

Tofalini**
RESUMO: Niketch: uma história de poligamia é um romance contemporâneo, publicado em 2002 pela autora moçambicana Paulina Chiziane. O seu conteúdo temático é daqueles cujo vigor narrativo (e poético), cujo encadeamento dramático e cuja transparência dos fatos ensejam uma boa discussão sobre a situação da mulher negra, inserida em um espaço pós-colonial, logo, tensionalmente antidemocrático, onde é possível observar os mecanismos da dominação masculina se inscrevendo nos corpos dos sujeitos por meio de vias simbólicas, conforme Bourdieu dérico, pois a predominancia da linguagem poética - emergente lirico, pois a predominância da linguagem poética - emergente da angústia da protagonista -, bem como a presença de outros elementos estruturais de natureza lírica, sugerem um enquadramento do texto nessa perspectiva classificatória. Fundamentam esta discussão: Bourdieu (2005) e Bakhtin (1998), dentre outros teóricos e críticos que se debruçam sobre o assunto.

PALAVRAS-CHAVE: Romance lírico; Poesia; Prosa; Habitus.
* jamestimao@hotmail.com

Mestrando do Programa de Pós-Graduação em Letras - Estudos Literários - da Universidade Estadual de Maringá (UEM).

*Iuziatofalini@hotmail.com

Doutora em Letras e docente do Programa de Pós-Graduação em Letras da Universidade Estadual de Maringá - PR. (UEM).

ABSTRACT: Niketche: A History of Polygamy is a contemporary novel, published in 2002 by Mozambican author Paulina Chiziane. Its thematic content is one of those whose narrative (and poetic) vigor, dramatic linkage and transparency of events lead to a good discussion of the situation of the black woman inserted in a post-colonial space. Thus, this place is obviously anti-democratic, where it is possible to observe the mechanis$\mathrm{ms}$ of male domination by inscribing themselves in the bodies of the subjects by means of symbolic ways, as Bourdieu (2005). This reflection on patriarchal supremacy is the starting point for preding predominance of poetic language - emerging from the anguish of the protagonist -, as well as the presence of other structura elements of a lyric novel, suggest a framing of the text in this classificatory perspective. This discussion is based on: Bourdieu (2005) e Bakhtin (1998), among other theoreticians and critics who dedicate themselves on this subject.

KEYWORDS: Lyric novel; Poetry; Prose; Habitus. 
1. BAKHTIN. Questôes de literatura e de estética: a teoria do romance, p. 397.

\section{CONSIDERAÇÕES INICIAIS}

A classificação de um gênero ou de um subgênero, quando focalizamos a esfera literária, é, quase sempre, um desafio que se interpõe entre o crítico e seu objeto analítico. O romance, gênero em permanente estado de mutação, conforme as considerações teóricas de Mikhail Bakhtin ${ }^{1}$, está longe de esgotar suas "possibilidades plásticas", pois os elementos que compõem sua estrutura são relativamente estáveis e, por isso, estão suscetíveis à hibridez. Surge, em decorrência desse fato, uma multiplicidade de subgêneros (o romance lírico, histórico, policial - só para citarmos alguns) que exige, do estudioso, uma análise mais acurada, a fim de se estabelece mais uma possibilidade de leitura - não esgotando, é claro, outras interpretações.

O nosso objeto de análise, Niketche: uma história de poliga mia, é um desses romances que nos colocam ante a um desafio: o de estabelecer uma classificação do texto em uma categoria narrativa capaz de abarcar certos elementos estruturais que se distanciam daqueles recorrentes no seio da poética romanesca convencional. Não raro, uma quantidade significativa de trabalhos de cunho científico tem abordado o romance em tela apenas sob o prisma da prosa poética. Entretanto, ainda que essa noção classificatória não esteja de todo modo equivocada, nossa hipótese - formulada a partir de repetidas leitura - permite-nos pressupor que o texto, de autoria de Paulina
Chiziane, é muito mais do que um romance cuja linguagem é altamente refinada, pois apresenta, em seu bojo, uma pluralidade de elementos que, somadas todas as suas partes, dá forma ao que se conhece por romance lírico.

É sobre essa categoria de ficção, aliás, que o nosso desafio se interpõe, a partir de dois motivos: o primeiro refere-se ao fato de que, conforme assinala Luzia Tofalini em Romance Lírico: os processos de liricização do romance de Raul Brandão (2013), as discussões concernentes a essa categoria narrativa, apesar de não serem, hoje, incipientes, exigem, por parte de quem o faz, uma atenção singular, uma vez que não há, ainda, uma fundamentação teórica capaz de proporcionar ao crítico, um embasamento consistente para orientar sua reflexão sem maiores problematizações.

O segundo motivo que justifica o nosso árduo desafio é em nossa compreensão - o mais importante, pois se trata de uma tentativa de analisar um romance (contemporâneo) de autoria feminina, cuja temática ainda não foi explorada nessa perspectiva de estudo. Esse romance foi publicado em 2002 e está inscrito numa linha de narrativa feminina africana de crítica à poligamia e, por isso, apresenta, em seu conteúdo, uma gama de questionamentos que diz respeito à situação da mulher negra, inserida em um espaço pós-colonial (logo, antidemocrático, se pensarmos no cerceamento dos direitos das mulheres), como é o caso de Moçambique - contexto 
de produção do texto. Desse modo, é clara a necessidade de trazer à baila desta discussão um aporte teórico - além daquele concernente às questões do romance lírico - que nos auxilie na compreensão dos mecanismos de reprodução da opressão patriarcal, pois advém deles o elemento essencial para a caracterização do texto lírico: a angústia.

\section{A DOR DA OPRESSÃO: ANGÚSTIA EM NIKETCHE}

Pierre Bourdieu foi, certamente, um dos grandes intelectuais do século XX pela incisiva atuação nos campos da antropologia e da sociologia, desenvolvendo pesquisas que avançaram por diversas áreas do conhecimento humano, como educação, cultura, política, arte, linguística, literatura - só para citarmos algumas. Mas é como sociólogo, dedicado à discussão do feminismo, que esse teórico nos interessa neste trabalho.

A Dominação Masculina, uma de suas obras de maior relevância nessa perspectiva de estudos, constituiu-se a partir de uma pesquisa de cunho etnográfico, realizada pelo autor entre as décadas de 1950 e 1960, no interior da sociedade Cabila - região localizada ao norte da Argélia. Em contato com essa sociedade, o pesquisador constatou que ela se organiza a partir do princípio androcêntrico, em que as relações sociais entre homens e mulheres se dão de forma assimétrica, com vantagens significativas para as pessoas de sexo masculino, cuja superioridade ${ }^{2}$ se constrói, sobre o feminino, na forma de habitus. Este termo, vale ressaltar, foi cunhado pelo autor para se referir ao modo como as estruturas sociais são incorporadas pelos indivíduos dessa sociedade ${ }^{3}$ a partir de disposições mentais e/ou cognitivas que os orientam em seus modos de sentir, pensar, agir etc.

Na obra em tela, Bourdieu lança-se à reflexão sobre dois aspectos importantes: 1) a permanência da dominação androcêntrica na contemporaneidade; 2) e o seu processo histórico de reprodução. A esse respeito, é preciso ponderar que o teórico não compreende a "ordem social das coisas" como um processo de representação ou uma ideologia, mas como um sistema de estruturas permanentes, as quais são perpetuadas tanto de forma subjetiva quando de forma objetiva, por meio de vias simbólicas - ou "violência simbólica", para falarmos nos termos do autor - uma vez que estão inscritas nos corpos e nas mentes dos sujeitos, não necessitando, portanto, de uma coerção física ou qualquer tipo de imposição direta sobre estes:

Também sempre vi na dominação masculina, e no modo como é imposta e vivenciada, o exemplo por excelência desta submissão paradoxal, resultante daquilo que eu chamo de violência simbólica, violência suave, insensível, invisível, a suas próprias vítimas, que se exerce essencialmente pelas vias puramente simbólicas da comunicação e do conhecimento.
2. Para Bourdieu, a "força da ordem masculina se evidencia no fato de que ela dispensa justificação: a visão androcêntrica impōe se como neutra e não tem necessidade de se enunciar em discursos que visem a legitimáa.. Cf. BOURDIEU. $A$ dominaçấo masculina, p. 18.

3. A noção de habitus, segundo o autor, tambem pode ser aplicada em muitas sociedades ocidentais.

4. BOURDIEU. $A$ dominação masculina, p. 7. 
5. BETTI. Pierre Bourdieu e a dominação masculina, p.02.

6. BOURDIEU. A dominação masculina, p. 44.
Sendo, pois, a violência simbólica uma violência "suave", "insensível", "invisível", a qual se coloca na ordem das coisas de maneira natural e que não precisa ser justificada, ela faz das diferenças biológicas entre os homens e as mulheres o seu fundamento natural e evidente. Isso se deve ao fato de que, para o sociólogo, a natureza biológica das pessoas, desde o Renascimento, passou a ser encarada como "fundamento da ordem social”, que determinaram as posições sociais dos sujeitos. Bourdieu ainda salienta que o ato da dominação é constituído a partir do seu reconhecimento e da sua reprodução pelos próprios indivíduos, pois as estruturas "históricas da ordem masculina são incorporadas na forma de habitus, ou seja, sob esquemas de percepção e de apreciação que determinam quais comportamentos e posturas são adequados aos homens e as mulheres" 5

Partindo do pressuposto de que a dominação masculina é reproduzida pelos sujeitos - homens e mulheres -, podemos afirmar, respaldados no estudo do teórico francês, que estas, no processo de incorporação do habitus, assumem para si o "preconceito desfavorável contra o feminino, instituído na ordem das coisas", confirmando "seguidamente tal preconceito" Em Niketche, a protagonista Rami, refletindo sobre sua condição de "ser mulher" na sociedade em que vive, ratifica essa proposição de Bourdieu ao apresentar, no plano da narrativa, o descontentamento para com seu gênero, quando afirma que ela e todas as outras mulheres são "o eterno problema e não há como solucioná-lo", já que são "um projeto imperfeito"?

É a partir da consciência de pertencer ao sexo feminino que Rami emana toda a sua angústia - elemento essencia para constituição do romance lírico. ${ }^{8}$ Esse sentimento, advindo das camadas mais profundas do ser, pode ser observado, pelo leitor, a partir de uma quantidade significativa de monólogos interiores utilizados pela romancista para dar voz à sua protagonista que, por várias vezes, extravasa suas emoções, inquietudes e anseios, lançando-se sempre a uma reflexão após algum incidente relevante. Em um desses encontros consigo mesma, Rami releva a sua lucidez em relação à supremacia masculina ao discutir, por meio de metáforas, as posições que o homem ocupa em seu espaço social: "Mulher é ser solitário na marcha da multidão. Mulher é a dor coletiva que cobre o mundo inteiro. É passado, presente e futuro, lugar e distância, ligadas pelo mesmo grito"'. Já o homem, na concepção da actante ${ }^{10}$, é o sujeito ereto, forte, situado no ponto mais alto de qualquer superfície - como o sol e a estrela, por exemplo - ou atuando como uma "seta implacável perfurando todas as curvas do universo para endireitar todos os caminhos do mundo" ${ }^{11 .}$

O homem é aquele por quem todos os sinos dobram. É aquele por quem todas as vozes se levantam, quando a morte o leva:
7. CHIZIANE. Niketche: uma história de poligamia, p.208.

8. É a presença da angústia que leva o ser humano a fazer um mergulho na sua própria interioridade onde os conteúdos ainda não cabem em palavras. Daí a necessidade de recorrência aos recu expressão poética.

CHIZIANE. Niketche: uma história de poligamia, p.218.

10. Emprestamos do semioticista russo, Algirdas Julien Greimas, o personagens da narrativa.

11. CHIZIANE. Niketche: uma história de poligamia, p.308. 
12. CHIZIANE. Niketche: uma história de poligamia, p.308-309.

13. CHIZIANE. Niketche: uma história de poligamia, p.11. era tão bom, que falta vai fazer, meu Deus! Homem é causa da dor das viúvas. Porque é um ser concreto. Perfeito. Altíssimo. Aquele que se procura e nunca se encontra. Todo homem um sucesso. Todo homem é um sol. É uma estrela que fala pelo silêncio e vive eternamente. Todo ele foi construído com geometria de santidade. E feito de retas. A sua imagem cresce em direção ao Sol. Como a estátua de Zeus tem os pés assentes nos extremos opostos diâmetros do mundo, por isso tudo tem que passar por baixo de suas pernas. Os navios. As águas doces dos rios. As multidões, os carros, os caminhões. E todas as mulheres do mundo. ${ }^{12}$

É bem verdade que, no contato com a obra, o interlocutor que (re)conhece os aspectos estruturais do romance lírico logo se dará conta de que a angústia presente no plano diegético difere daquela comumente caracterizada a partir de uma perspectiva existencial - como em Húmus, de Raul Brandão. Como já afirmamos, a angústia que permeia a obra de Paulina Chiziane emerge da violência simbólica, isto é, da inclinação natural da mulher ao homem. Nessa perspectiva tal inclinação implica, além de outros fatores, dependência da mulher em ter um sujeito masculino ao seu lado, pois, em uma sociedade patriarcal, "um marido em casa é segurança, é proteção. Na presença de um marido, os ladrões se afastam. Os homens respeitam."13
Até mesmo o leitor desavisado é capaz de observar, no romance ora discutido, que Rami sofre intensamente pela ausência de Tony - seu marido - o qual, por vários dias, deixou de frequentar o seu lar para encontrar-se com suas amantes. "Onde andas, meu Tony, que não te vejo nunca? Onde andas, meu marido, para me protegeres, onde? Sou uma mulher de bem, uma mulher casada. Uma revolta interior envenena todos os meus caminhos. Sinto vertigens." ${ }^{14}$ Emerge dessa carência afetiva a angústia da narradora que, incessantemente, apresenta o seu mundo subjetivo - espaço onde as emoções ofuscam as ações ocorridas no plano exterior da trama. É partir dessa constatação que nossa hipótese vai se confirmando, pois "diante da tendência lírica, as ações das personagens, relacionadas ao mundo exterior, não adquirem relevo, porque, no texto narrativo lírico, o que sobressai é o mundo interno, subjetivo." ${ }^{15}$ Eis um exemplo:

Fecho os meus olhos e escalo o monte para dentro de mim. Procurome. Não me encontro. Em cada canto do meu ser encontro apenas a imagem dele. Solto um suspiro e só me sai o nome dele. Desço até ao âmago do meu coração e o que encontro? Só ele. Tenho por ele um amor puro e perfeito, será que ele não vê? ${ }^{16}$

Ainda no que tange à angústia, um fato importante a ser observado em nossa discussão remete-se ao desaparecimento de Tony. No decorrer da trama, emerge a suspeita de que
14. CHIZIANE. Niketche: uma história de poligamia, p.10.
EM TESE
BELO HORIZONTE

v. 22
15. TOFALINI. Romance lírico: 0 processo de "liricização" do romance de Raul, p.164.

6. CHIZIANE. Niketche: uma história de poligamia, p.12. 
17. CHIZIANE. Niketche: uma história de poligamia, p. 201.

18. CHIZIANE. Niketche: uma história de poligamia, p.220-221.

19. CHIZIANE. Niketche: uma história de poligamia, p.204. ele havia sido morto, vítima de um atropelamento. Após o incidente, ocorrido à beira de uma ponte, "num só instante, extraíram a certidão do morto e marcaram o funeral" ${ }^{17}$, sem realizar o processo de identificação do corpo. E é na cerimônia fúnebre, organizada às pressas, que encontramos, novamente, nossa heroína em mais um profundo lapso de angústia:

Aquele morto que desce liberta em mim uma angústia. Já não quero saber de mais nada nesta vida. Um manto de recordações amargas invade a minha mente como pirilampos. Sinto uma noite imensa a abraçar-me a alma e encosto meu o meu corpo nas paredes do horizonte. O Tony acaba de morrer agora, no corpo deste estranho. Já não quero mais vê-lo, tudo morreu. [...] O mundo inteiro olhará para ele, segundo o retrado que esculpiu sobre si próprio. Homem vivo que se fez de morto. Meu Deus, tende piedade do Tony. Tende piedade de todos os homens que cometem os crimes mais hediondos em nome de uma tradição e de uma cultura. ${ }^{18}$

No fragmento acima, é-nos evidente a angústia da personagem. Mas o que a justifica se, a todo o momento, ela esteve ciente de que aquele corpo "não tinha nada a ver com o Tony"? ${ }^{19}$. Essa pergunta pode ser mais bem respondida se insistirmos na proposição de que é a dor da opressão (masculina), operada por meio de vias simbólicas, a causa crucial do sentimento de Rami que, tomada por "recordações amargas", não encontra outra maneira de se expressar senão através de construções sintáticas essencialmente poéticas.

Até o presente momento, detivemos nosso foco apenas na personagem Rami - figura feminina que tem apresentado, sob múltiplos aspectos, as marcas da dominação masculina Mas, antes de encerrarmos este tópico, cuja finalidade é discutir, com maior propriedade e melhor entendimento sobre esse elemento crucial para caracterização do romance lírico, é preciso pontuar que, na compreensão de Bourdieu, os homens também são vítimas da representação dominante, uma vez que "ser homem, no sentido de vir, implica um dever-ser, uma virtus, que se impõem sob a forma do é evidente por si mesma, sem discussão". ${ }^{20}$

Nesse sentido, entendemos que a dominação masculina também está inculcada nos corpos dos homens por meio de um habitus, fazendo-os adotar algumas posturas que os confirmem em sua masculinidade, como, por exemplo, a atitude de colocarem-se sempre em pé com o corpo ereto, de cabeça erguida, em obediência a uma linhagem submetida às exigências da ordem simbólica. Por isso a "macheza" do sujeito tem de ser "validada pelos outros homens, em sua verdade de violência real ou potencial e atestada pelo reconhecimento de fazer parte de um grupo de "verdadeiros homens"'21. Prossegue o teórico:
20. BOURDIEU $A$ dominação masculina, p. 63. 
22. BOURDIEU. $A$ dominação masculina, p. 66.

23. CHIZIANE. Niketche: uma história de poligamia, p.302, grifo nosso.
Certas formas de "coragem", as que são exigidas ou reconhecidas pelas forças armadas, ou pelas polícias (e, especialmente, pelas corporações de elites), e pelos bandos de delinquentes, ou também, mais banalmente, certos coletivos de trabalho [...] encontram seu princípio, paradoxalmente no medo de perder a estima ou a consideração do grupo, de quebrar a cara diante dos companheiros e der remetido a categoria, tipicamente feminina, do "fracos", dos "delicados", dos mulherzinhas", dos "veados". ${ }^{22}$

Podemos observar, no curso da narrativa, que Tony sofre com a ausência de suas amantes quando estas alcançam o sucesso financeiro. Todavia, seu sofrimento, vale lembrar, não está relacionado a um simples sentimento afetivo, pois, no jogo da dominação, o personagem masculino vê-se vencido ao perder o "respeito" e as regalias proporcionadas por suas mulheres-objetos, as quais sempre estavam dispostas a lhe servir, como demonstra o seguinte excerto:

- Já não me servem de joelhos como antes, não me massageiam os pés quando descalço os sapatos. Ultimamente, quem me abre a porta é o criado, porque elas nunca estão em casa. Só tem a cabeça nos negócios e dizem que estão ocupadas. ${ }^{23}$

Considerando as proposições de Bourdieu, atentemo-nos, novamente, para a profissão exercida pelo marido de Rami: ele é comandante de polícia, logo está inserido em um ambiente que exige do homem, a ratificação de sua masculinidade. Advém daí a justificativa para sua angústia, pois, ao perder suas mulheres, ele perde também a sua honra; ${ }^{24}$ não podendo, portanto, afirmar-se diante de seu grupo, o que o levará, consequentemente, à perda e à desconsideração dos demais membros da corporação militar: "Mas o que dirá o mundo? Todos os homens zombarão de mim. Todos duvidarão da minha virilidade e serei motivo de chacota. Dirão que entrei na andropausa. Que estou a perder os meus poderes. Que deixei a gaiola aberta por incompetência." ${ }^{25}$

Diante do exposto, evidencia-se que a dominação masculina é uma forma opressora altamente complexa, cujos mecanismos de reprodução das vias simbólicas - o habitus - não excluem sequer os homens de seu sistema. Na trama de Paulina Chiziane, Tony é apresentado a partir do ponto de vista de Rami, a qual não se limita a descrever, também, a angústia masculina, por meio de uma enunciação egocentralizada ${ }^{26}$ em que as construções sintáticas ganham contornos propriamente poéticos.

O coração do homem quebra em mil pedaços. Honra, dignidade, orgulho, vaidade, são ondas imensas onde ele todo se afunda. Está no precipício. A sua alma mergulha num oceano fundo. Não se sabe nadar. Olha para o céu, talvez à procura de Deus. Desvia os olhos para o horizonte, galgando as nuvens como gaivotas no final da primavera. O horizonte é uma muralha distante, onde
24. O ponto de honra, na compreensăo de Bourdieu (2005, p.62), consiste no conjunto de estratégias de perpetuação dos privilégios concedidos aos homen (por meio de sua linhagem) que, detendo o monopólio dos instrumentos de produção e de reprodução do capital simbólico, vis manutenção desse capita.

25. CHIZIANE. Niketche: uma história de poligamia, p.271, grifo nosso.

26. GOULART. O trabalho da prosa: Narrativa, ensaio e epistemologia, 2007. 
27. CHIZIANE. Niketche: uma história de poligamia, p.228.

28. Ver Romance Lírico: Os processos de liricização do romance de Raul

29. BAKHTIN. Questões de literatura e de estética: a teoria do romance, p. 397.

30. FASCINA; TOFALINI. Água viva: um romance lírico de Clarice Lispector, p.2. tudo é fim, tudo é princípio. No horizonte encontra o reflexo triste da sua imagem. Ele fica hirto, seco, como um homem morto. Nem um movimento, nem gestos, nem palavras. ${ }^{27}$

\section{NA CONFLUÊNCIA DA PROSA E DA POESIA: RAMI}

\section{UMA NARRADORA LÍRICA}

Quando nos dispomos a estudar a obra de Paulina Chiziane sob o prisma do romance lírico, sabíamos que encontraríamos - e não haveria de ser por menos - certa dificuldade de conjugar seus elementos estruturais de maneira didática. A estrutura que engendra esse tipo de romance possui elementos interdependentes que só um trabalho de maior fôlego daria conta de se deter a cada uma de suas especificidades, como o estudo de Luzia Tofalini ${ }^{28}$, por exemplo. Por esta razão, faremos, neste momento, um breve percurso sobre a hibridez do gênero romance para, em seguida, justificarmos a liricidade da narradora.

Ao retomar as considerações do teórico russo, Mikhai Bakhtin, é de nosso entendimento que "a ossatura do romance enquanto gênero está longe de ser consolidada, e não podemos ainda prever todas as suas possibilidade plásticas." ${ }^{29}$ Justifica-se, assim, a maleabilidade desse gênero que permite mesclar poesia e prosa de tal modo que a "denominação de lírico seja uma de suas inúmeras mutações." ${ }^{30}$ Nesse viés, uma consideração de Tofalini (2013) nos é bastante oportuna:
É preciso, porém, mergulhar no âmago da prosa e da poesia para observar que mundividência elas carregam dentro de si. Não é raro poesia e prosa andam juntas na mesma obra. Esse fato se justifica porque, além de não serem posições estanques, pois nem sempre sabemos onde termina o 'eu' e começa o 'não-eu', e vice-versa, ambos se nutrem da mesma seiva subjetiva e deformadora da realidade. ${ }^{31}$

De fato, prosa e poesia podem, sim, atuar em confluência em uma mesma obra. É bem verdade que cada uma dessas formas de expressão possui suas respectivas particularidades, como é o caso da poesia que não depende do verso, mas da utilização de recursos expressivos, tais como métrica, ritmo, imagens, símbolos, alegorias etc.

Acontece que, no romance lírico - observam Tofalini e Fascina - essas peculiaridades, sobretudo as que concernem ao ritmo, "não obedecem a uma regularidade absoluta, o que não prejudica, pelo contrário, confere equilíbrio à frase, pois a mescla dos ritmos da prosa e da poesia confirmam novamente a hibridez do gênero"32: "Mulheres, mulheres, mulheres. Mulheres salvação, mulheres perdição. Foi por causa das mulheres que Tony armou esta trama.É por haver mulheres a mais que se engasgou de tanta gula. Fez do amor suicida um samurai, kamikasi, naparama"33. A repetição das palavras 'mulheres' e, por conseguinte, a anáfora que se segue nas frases acima, não ocorre de maneira gratuita no texto, assim como as palavras
31. TOFALINI. Os processos de liricização do romance de Raul Brandâo, p.84.
EM TESE
BELO HORIZONTE
v. 22
N. 3
SET.-DEZ. 2016
SANTOS; TOFALINI. Na confluência da prosa e da poesia: Niketche [...]
P. 294-308

32. FASCINA; TOFALINI. Agua viva: um romance lírico de Clarice Lispector, p.8.

33. CHIZIANE. Niketche: uma história de poligamia, p.244, grifo nosso. 
34. ROSENFELD. Reflexôes sobre o romance moderno, 1973

35. TOFALINI. Os processos de liricização do romance de Rau Brandão, p.92. 'trama' e 'naparama' também estão longe de ser uma construção inocente. É a poesia ditando ritmo à prosa, formando um coro uníssono com ela em perfeita harmonia.

Avançando em nossa discussão, Anatol Rosenfeld ${ }^{34}$ prenunciara que o fenômeno da desrealização - observado primeiramente na pintura - sucumbiu das telas a realidade empírica. O autor observa, ainda, que, no romance, tempos depois, já era possível observar as tramas romanescas orientando-se à reprodução da realidade apreendida pelos sentidos, isto é, pela subjetividade. Daí a justificativa para obras de caráter instrospectivo, notadamente observável em autores como Clarice Lispector, Raul Brandão e, em nosso caso, Paulina Chiziane, os quais traduzem em construções essen cialmente poéticas, os sentimentos de seus personagens, principalmente quando estes se voltam para os seus redutos mais íntimos, onde, segundo Tofalini "reina a poesia" ${ }^{35}$.

Há diferentes espécies de angústia. Entre elas podemos contar aquela de cunho existencial, a psicanalítica e a que estamos tratando aqui: aquela que resulta da dominação masculina. Assim, a dor que permeia a obra de Paulina Chiziane não pode ser expressa senão por meio da poesia, uma vez que a forma mais objetiva (prosaica) de narrar é incapaz de expressar aquilo que é da profundidade do ser. No excerto a seguir demonstramos a necessidade da poesia no texto de Chiziane:
Étarde, o sol sorri em despedida. Estou no meio de sombras. Sombras que se levantam e caem ao ritmo do sol de cada dia. Chegou a hora fatal, o caixão desce às goelas da terra, essa pescadora de corpos, com túmulos, com tentáculos invisíveis. Nem as palavras nem as preces podem impedir o voo final. Há um pacto entre a dor e o silêncio. Entre murmúrios e lágrimas. $\mathrm{Na}$ imagem do morto, o reflexo da sorte. Todos somos mortais. Morte é fruta madura emancipando-se da árvore para seguir o seu próprio caminho. ${ }^{36}$

No fragmento acima, o sujeito que enuncia se encontra "em no meio das obras" - espaço este localizado nas profundezas do 'eu'. É justamente nessa camada mais interior desse ser, emaranhado pela angústia, que o leitor é convidado a percorrer umas das vias mais líricas do romance, guiado pela voz estritamente poética de uma narradora autodiegética que recria o seu espaço e subverte a ordem do universo: "o sol sorri em despedida" e as sombras "se levantam e caem no ritmo de cada dia", permitindo que o tempo seja presentificado à mercê de quem discursa. E em meio a essa (des)construção das coisas, a "terra" ganha contornos humanos como que uma persona constituída por "goelas" e, desprendida de qualquer compromisso com a realidade exterior, torna-se "pescadora de corpos”. Em síntese, o que se nota aí é o modo lírico acrescentando ao narrativo "o que é o domínio da intensidade emocional, da subtileza enunciativa, da metaforicidade, da polissemia
36. CHIZIANE. Niketche: uma história de poligamia, p.220, grifo nosso.

EM TESE $\quad$ BELO HORIZONTE $\quad$ v. $22 \quad$ N. $3 \quad$ Set.-DEz. $2016 \quad$ SANTOS; TOFALINI. Na confluência da prosa e da poesia: Niketche [...] $\quad$ P. 294-308


37. GOULART. O trabalho da prosa: Narrativa, ensaio e epistemologia, p.20.

38. FREEDMAN. La novela lírica: Hermann Hesse, Andre Gide y Virginia Woolf, p. 245

39. CHIZIANE. Niketche: uma história de poligamia, p.244, grifo nosso. ao mais alto nível, da construção de uma expressão artística musical que sugira o que não pode dizer directamente, nomeie o inominável e persiga mesmo o absoluto" ${ }^{37}$.

Niketche possui uma gama de personagens que não apenas compõe o cenário figurativo da trama, mas que assume funções extremamente necessárias para sequência das ações. Contudo, - e já tratando de comprovar, novamente, noss hipótese - estamos falando de uma instância narrativa predominantemente lírica, em que o " yo' lirico se convierte em e protagonista, que remodela el mundo por médio de sus percepciones y ló interpreta como una forma de la imaginacion"38.

No casamento, as mãos das mulheres são conchas abertas sobre a areia do mar, mendigando amor, pão, sal e sabão. O casamento significa subir para um trono de lenha e aguardar a hora da fogueira. O casamento é romântico. Nos homens inspira mel e doçura. Inspira felicidade e ternura. Nas mulheres, inspira lágrimas, mágoas, desterro e morte. Inspira um mundo de loucura como este que estou a viver agora. ${ }^{39}$

Rami, como há de se ter percebido pelo exposto até aqui, narra sua história por meio de uma linguagem notadamente simbólica, imagética e, não obstante, sugestiva, como o excerto acima, em que ela, situada em um dado contexto social, interpreta, a seu modo (lírico), a reconfiguração das relações matrimoniais vigentes em sua sociedade.

\section{O SILÊNCIO DAS MULHERES EM NIKETCHE}

O estudo do silêncio, principalmente quando este é utilizado a favor de uma compreensão mais substancial das categorias poéticas presentes no romance lírico, contribui, também, "para a construção da imagem poética na palavra esvaziada de seus significados, pois no texto em questão, o tratamento do código verbal escrito é elevado a um níve mais sensorial, mais visual, provocando e necessitando da imaginação do leitor" ${ }^{\prime 40}$. Nesse sentido, podemos afirmar que, em Niketche, são várias as passagens em que o leitor é induzido a se desprender do código escrito para contemplar as imagens construídas pela linguagem poética.

Os pássaros erguem-se em revoada na árvore em queda. Os macacos se espantam, caem e gritam. As cobras desmaiam e despertam. A fruta solta-se e se espalha. O vento ulula na tempestade da morte. Depois do espanto segue-se o silêncio. Um minuto de silêncio apenas. O passo a seguir é recolher o espólio e partir para novas sombras. ${ }^{41}$

Integrado ao seu contexto na trama, o fragmento acima é puramente metafórico. A narradora, como em outros momentos de intensa reflexão, apresenta ao narratário, o seu mundo subverso. O sentimento que envolve a personagem, nesse excerto, é fruto da submissão a seu marido, e só pode ser expresso através de construções conotativas - tão comuns
40. FASCINA; TOFALINI. Água viva um romance lírico de Clarice Lispector, p.12.

41. CHIZIANE, Niketche: uma história de poligamia, p.231.
EM TESE
BELO HORIZONTE
v. 22
N. 3
SET.-DEZ. 2016
SANTOS; TOFALINI. Na confluência da prosa e da poesia: Niketche [...] P. 294-308 
42. FASCINA; TOFALINI, Água viva: um romance lírico de Clarice Lispector, p.14.

43. ORLANDI, As formas do silêncio: no movimento dos sentidos, p.47.

44. ORLANDI, As formas do silêncio: no movimento dos sentidos, p.47.

45. Ver ORLANDI, Eni Pucinelli. As formas do silêncio no movimento dos sentidos. Campinas: Unicampi 1997

46. CHIZIANE, Niketche: uma história de poligamia, p.175.

47. ORLANDI, As formas do silêncio: no movimento dos sentidos, p.81. para formações imagéticas. Mas quando o leitor depara-se com o silêncio, ("Depois do espanto segue o silêncio. Um minuto de silêncio apenas"), ele é induzido a realizar outras leituras "no campo analógico" ${ }^{42}$, pois, o que está silenciado não é "diretamente observável" ${ }^{43}$, mas possui significações a serem decodificadas pelo interlocutor.

Há, ainda, na obra aqui discutida, diversas manifestações do silêncio: "o silêncio das emoções, o místico, o da contemplação, o da introspecção, o da revolta, o da resistência, o da disciplina, o do exercício do poder, o da derrota, da vontade etc." ${ }^{44}$. Mas, de todas elas, não poderíamos deixar de mencionar, aqui, aquelas "ocorrências" diretamente ligadas à política do silêncio ${ }^{45}$, mais precisamente no aspecto concernente à censura, pois, em uma sociedade androcêntrica - como é o caso do espaço ficcional por onde transitam as personagens - "as vozes das mulheres censuram-se em uníssono" ${ }^{46}$, a ponto de o silêncio manifestar-se, paradoxalmente, de maneira gritante no fio do discurso ficcional. Podemos defender, portanto, a tese de que a dominação e tantas outra formas de opressão, notadamente presente nas ações dos personagens masculinos - principalmente de Tony - tendem a silenciar a voz e a identidade feminina, ratificando a proposição de Eni Orlandi, a qual compreende que a censura "é a interdição manifesta da circulação do sujeito, pela decisão de um poder de palavra fortemente regulado afeta, de imediato, a identidade do sujeito" ${ }^{\prime 7}$.
Cerramos nossas bocas e as nossas almas. Por acaso temos direito à palavra? E por mais que a tivéssemos, de que valeria? Voz de mulher serve para embalar as crianças ao anoitecer. Palavra de mulher não merece crédito. Aqui no sul, os jovens iniciados aprendem a lição: confiar numa mulher é vender a tua alma. Mulher tem língua comprida de serpente. Mulher deve ouvir, cumprir e obedecer. ${ }^{48}$

Já é de nosso conhecimento que a dominação masculina opera por meio de mecanismos quase imperceptíveis, inscrevendo, nos corpos dos sujeitos (masculinos e femininos), suas inclinações e aptidões, orientando-os em seu comportamento nos espaços sociais. Desse modo, é de se esperar que as mulheres, dominadas pelo sistema adrocêntrico, as sumam, para si, não apenas o preconceito de sua própria feminilidade, mas, também, o seu próprio silenciamento. Rami é assim: uma personagem que se põe a refletir sobre a questão feminina, e, com poesia, apresenta ao interlocutor a sua (cons)ciência de que, na sociedade em que vive, "as mulheres são um mundo de encanto e de silêncio" ${ }^{49}$.

\section{TEMPO E ESPACO: CATEGORIAS NARRATIVAS}

\section{LIRICIZADAS}

Com base nos estudos que se debruçam sobre as categorias narrativas, nota-se, entre os teóricos, que é consenso a assertiva de que ação, personagem e espaço - acrescentemos
48. CHIZIANE, Niketche: uma história de poligamia, p.154.

49. CHIZIANE. Niketche: uma história de poligamia, p. 160
EM TESE
BELO HORIZONTE
v. 22
N. 3
SET.-DEZ. 2016
SANTOS; TOFALINI. Na confluência da prosa e da poesia: Niketche [...] P. 294-308 
50. MOISÉS. A criação literária: prosa $1, \mathrm{p} .182$

51. ROSENFELD. Reflexões sobre o romance moderno, p.81.

52. TOFALINI. Os processos de liricização do romance de Rau Brandẫo, p.177.

53. CASTAGNINO apud TOFALINI. Os processos de liricização do romance de Raul Brandão, p.177. aí também o tempo ("a quarta dimensão posta em evidência em nossos dias" ${ }^{\prime 0}$ ) - engendram o quadro de elementos substanciais para a caracterização do gênero romance. Tanto o espaço quanto o tempo, elementos estruturais sobre os quais iremos nos ater neste tópico, assumem contornos específicos em narrativas modernas, pois, em conformidade com as considerações críticas de Rosenfeld ${ }^{51}$, é notória, nessas manifestações prosaicas, a rarefação da ordem cronológica, em que o romancista, amparado pela liberdade criadora que lhe é concebida, funde passado, presente e futuro, desvencilhando-se dos compromissos formais com a tradição romanesca.

Em se tratando do romance lírico, podemos afirmar que nesse subgênero, a transfiguração - ou a fusão, que seja - das categorias narrativas ora discutidas, alcança uma dimensão mais elevada, pois estas estão sob o jugo da "cosmovisão da poesia" ${ }^{2}$. Justifica-se, assim, o fato de "as personagens optarem por uma temporalidade própria e eleger o tempo da emoção e do pensamento como valor elevado do ser humano, até porque no "[...] transcender lírico, a subjetividade sublima o tempo e se sublima na temporalidade" ${ }^{23}$.

No ato da leitura, o interlocutor de Paulina Chiziane certamente irá se deparar com uma obra predominante subjetiva. Isso não quer dizer, por outra via, que não há, na trama, uma quantidade significativa de ações contínuas. Pelo contrário Elas estão lá. E até permitem, ao leitor, observar tal linearidade.
Esta, todavia, é fragmentada em detrimento da presentificação do tempo que "eclode das profundezas da subjetividade da personagem ${ }^{\prime 54}$ Rami, como ratifica o extrato abaixo:

Desperto inspirada. Hoje quero mudar o meu mundo. Hoje quero fazer o que fazem todas as mulheres desta terra. Não é verdade que pelo amor se luta? Pois hoje quero lutar pelo meu. Vou empunhar todas as armas e defrontar o inimigo, para defender o meu amor. Quero tocar na alma de todas as pedras do meu caminho. Quero beijar grão a grão a areia que tece o solo fecundo onde me aleito. Fecho os ouvidos ao mundo e apenas escuto o silêncio do meu percurso. Escuto o som intermitente da chuva miúda caindo da vidraça ${ }^{55}$.

Ocorrendo a fragmentação da linearidade temporal da narrativa a partir das incursões subjetivas de Rami, é possível notabilizar a estatização do tempo. "Durante dias e dias procuro ouvir a voz da minha consciência”. São inúmeras páginas em que observamos o 'eu' revisitando o seu abissa e, encontrando-se com a poesia, discursa por meio de uma linguagem simbólica, imagética, para enunciar o indizível. Nesse sentido, é preciso ressaltar o fato de o tempo da poesia ser um "tempo polimorfo, feito da convergência do tempo do presente da enunciação, da contemplação extática, da ressonância emotiva, a que se alia não raro o tempo primordial, arquetípico, igualmente não evolutivo"56.
54. CHIZIANE. Niketche: uma história de poligamia, p.61.
55. CHIZIANE Niketche: uma história de poligamia, p.19. 
57. DIMAS. Espaço e romance, p.5-6.

58. BOTOSO; PIOLA. O espaço ficcional em Niketche, p.52.
Antes de iniciarmos nossa discussão sobre o espaço, é digna de nota a obra Espaço ficcional em Niketche: uma historia de poligamia e A paixão segundo GH, de Altamir Botoso e Raque Piola, os quais apresentam um estudo minucioso acerca dessa categoria narrativa. O trabalho dos autores irá nos auxiliar em nossa reflexão ainda que eles não se detenham à transfiguração do espaço, pois, antes de qualquer coisa, esse elemento estrutural do romance alcança um "estatuto tão importante quanto outros componentes da narrativa, tais como foco narrativo, personagem, tempo, estrutura etc." ${ }^{57}$.

Consoante ao que temos proposto neste artigo, podemos afirmar, de acordo com Botoso e Piola que os aspectos concernentes à dominação masculina têm influência direta também sobre o espaço em Niketche, pois, embora os deslocamentos de Rami "não sejam muito longos, pelo menos é isso que fica patente em sua narração, é também certo que o ato de percorrer diferentes bairros, distintas casas, significa, sim, uma realização de seu destino, uma busca por mudanças que alterem o seu estado de submissão" ${ }^{\text {58 }}$. É desta submissão, aliás, que emerge a angústia que transfigura o espaço ficcional, fazendo com que a personagem volte para dentro de si, em uma incursão essencialmente lírica.

Preciso de um espaço para repousar meu ser. Preciso de um pedaço de terra. Mas onde está minha terra? Na terra do meu marido? Não, não sou de lá. Ele me diz que não sou de lá, e se os espíritos de sua família não me quiserem lá, podem me expulsar de lá. O meu cordão umbilical foi enterrado na terra onde nasci, mas a tradição diz que eu também não sou de lá. $\mathrm{Na}$ terra do meu marido sou estrangeira. $\mathrm{Na}$ terra dos meus pais sou passageira. Não sou de lugar nenhum. Não tenho registro, no mapa da vida não tenho nome. Uso este nome de casada que me pode ser retirado a qualquer momento. Por empréstimo. Usei o nome paterno que me foi retirado. Era empréstimo. A minha alma é minha morada. Mas onde vive a minha alma? Uma mulher sozinha é um grão de areia no espaço que o vento varre para lá e para cá, na purificação do mundo. Uma sombra sem sol, nem solo, nem some. ${ }^{59}$

Diante do exposto, é possível constatar que o espaço de que fala Rami é o da própria interioridade, ainda que tenhamos, no plano diegético, diversos locais físicos bem delineados. Quando a narradora enuncia: "A minha alma é minha morada" ${ }^{60}$, ela se refere a um espaço simbólico, metonímico, propício para uma intensa reflexão, "que emerge das profundezas da intuição e se derrama pelo discurso narrativo"61 sobre a condição feminina: "Uma mulher sozinha é um grão de areia no espaço que o vento varre para lá e para cá, na purificação do mundo."62

Há inúmeras outras ocorrências em que se é possível observar a introspecção da protagonista. Uma delas, também digna de nota, é o momento em que ela, após um lapso de
59. CHIZIANE. Niketche: uma história de poligamia, p.90.

60. CHIZIANE. Niketche: uma história de poligamia, p.19.

61. TOFALINI. Os processos de liricização do romance de Raul Bririzaçãao do rom.

62. HIZIANE. Niketche: uma história de poligamia, p.90.
EM TESE
BELO HORIZONTE
v. 22
N. 3
SET.-DEZ. 2016
SANTOS; TOFALINI. Na confluência da prosa e da poesia: Niketche [...]
p. 294-308 
63. BOTOSO; PIOLA. O espaço ficcional em Niketche, p.70

64. CHIZIANE. Niketche: uma história de poligamia, p.32 e 171. tristeza, volta-se para o espelho para buscar consolo. "É a própria narradora quem enfatiza a importância da sua imagem refletida no espelho como o seu alter-ego e também com o seu lado inconsciente que se manifesta nos momentos em que ela se olha no espelho e deixa brotar todos os seus sentimentos." ${ }^{63}$ Eis um exemplo da obra:

-Diz-me, espelho meu: serei eu feia? [...] Por que é que o meu marido procura outras e me deixa aqui? O que é que as outras têm que eu não tenho? [...]

O espelho me responde com malícia:

-Ah, sua gorda!

-Não! Não achas que emagreci um pouco?

-Emagreceste, sim.

-Graças a Deus não precisei de chá nem dietas.

-Vês como o teu marido é bom? Deu-lhe um desgosto benéfico, que emagrece. [...]

Vou ao quarto e dialogo com o meu espelho.

- Espelho meu, o que será de mim?

O espelho dá-me uma imagem de ternura e responde com a maior lucidez de sempre.

- Não serás a primeira a divorciar, nem a última. Os divórcios acontecem todos os dias, como os nascimentos e as mortes, mas tranquiliza-te. [...]. ${ }^{64}$
Conforme assinalaram Botoso e Piola, o espelho que, no caso de Rami, funciona como o seu alter-ego, ratifica a proposição de Tofalini, a qual compreende que o "verdadeiro espaço do romance lírico tem a extensão da consciência do homem" ${ }^{15}$. Nessa e em todas as outras incursões interiores em que foi possível observar a angústia da personagem traduzida em linguagem densamente poética, podemos afirmar, sem nenhum receio, que elas constituem o todo de um espaço ficcional transfigurado, pois este "transcende a realidade física" e "adentra o universo à procura de respostas e à procura de poesia [...]"66.

\section{CONSIDERAÇÕES FINAIS}

A obra a que nos propusemos a analisar abre margem para diversas possibilidades interpretativas e pode ser analisada sob a perspectiva de múltiplos aspectos. Empreendemos uma análise que teve intuito de apontar as categorias narrativas que compõem a estrutura composicional do romance lírico, a fim de colaborar com uma leitura mais acurada da narrativa. Advém daí a justificativa para uma discussão que se preocupou em atentar, substancialmente, para a angústia - um elemento de fundamental importância para caracterização de um texto de natureza lírica, conforme Tofalini.

Parafraseando Tofalini, Paulina Chiziane é uma prosadora-poeta-filósofa do terceiro mundo. E o saldo de tudo isso é Niketche: uma obra monumental em que o leitor é convidado
65. TOFALINI. Os processos de liricização do romance de Rau Brandâo, p.178-179.

66. TOFALINI. Os processos de liricização do romance de Raul Brandão, p.179. 
a inebriar-se com uma trama minuciosamente elaborada, e celebrar a confluência manifesta da poesia com a prosa, que formam um coro uníssono para aferir frescor à crítica da autora ao sistema patriarcal. Niketche é um convite ao silêncio, à contemplação, à reflexão... É um convite a todo aquele que deseja (re)visitar o reduto mais íntimo das mulheres inseridas em um espaço pós-colonial, as quais sentem, na inscrição de seus próprios corpos, as marcas da dominação androcêntrica. Em suma, Niketche é um romance lírico não apenas pela conjugação de todas suas categorias narrativas, mas pela liricidade que emana de todas as vozes presentes no fio desse discurso ficcional.

\section{REFERÊNCIAS}

BAKHTIN, Mikhail Questões de literatura e de estética: a teoria do romance. Tradução de Aurora Fornoni Bernardini, Jose Pereira Junior, Augusto Goes Junior, Helena Spryndis Nazário e Homero Freitas de Andrade. São Paulo: Unesp, 1998

BETTI, Marcella. Pierre Bourdieu e a dominação masculina. Lab. Didático. São Paulo: Edusp, 2011

BOTOSO, Altamir; PIOLA, Raquel. O Espaço ficcional em Niketche: uma história de poligamia e A paixão segundo G.H. 1.ed. Bauru: Canal 6, 2012

BOURDIEU, Pierre. A dominação masculina. Trad. Maria Helena Künher. 4. ed. Rio de Janeiro: Bertrand Brasil, 2005.
CHIZIANE, Paulina. Niketche: Uma história da poligamia. São Paulo: Companhia das Letras, 2004.

DIMAS, António. Espaço e romance. 2.ed. São Paulo: Ática, 1987.

FASCINA, Diego Miiiler; TOFALINI, Luzia Berlofa Água viva: Um romance lírico de Clarice Lispector. Cascavel: Revista Línguas \& Letras, 2013. p.1-16.

FREEDMAN, Ralph. La novela lírica: Hermann Hesse, Andre Gide y Virginia Woolf. Tradução de Jose Manuel Llorca. Barcelona: Barral editores, 1972

GOULART, Rosa Maria. O trabalho da prosa: Narrativa, ensaio e epistemologia: Braga/Coimbra: Angelus Novus, 1997.

MOISÉS, Massaud. A criação literária: Prosa I. São Paulo. Cutrix 2006

ORLANDI, Eni de Lourdes Puccinelli. As formas do silêncio: no movimento dos sentidos. 4. ed. Campinas: Ed. Unicamp, 1997.

ROSENFELD, Anatol. Texto/Contexto. 2ed. São Paulo:

Perspectiva/ Brasília INL, 1973.

TOFALINI, Luzia Berloffa. Romance lírico: o processo de "liricização" do romance de Raul Brandão. Maringá: Eduem, 2013 